\title{
STUDI PENGARUH UMUR DAN JENIS KELAMIN PADA PASIEN TUBERKULOSIS DI RUMAH SAKIT DKT PURWOKERTO
}

\author{
Peppy Octaviani ${ }^{1)}$ Ikhwan Yuda Kusuma ${ }^{2)}$ \\ ${ }^{1), 2)}$ Program Studi Farmasi Sekolah Tinggi Ilmu Kesehatan Harapan Bangsa Purwokerto \\ 1) peppyoctaviani@shb.ac.id, ${ }^{2)}$ Ikhwanyuda@shb.ac.id
}

\begin{abstract}
ABSTRAK
Tuberkulosis (TB) paru merupakan penyakit infeksi paru menular yang masih menjadi masalah kesehatan di dunia terutama negara berkembang. Penyakit tuberkulosis sudah dicanangkan oleh WHO (World Health Organization) sebagai Global Emergency sejak tahun 1992. Tujuan penelitian ini untuk mengetahui apa saja karakteristik fisik yang beresiko terhadap penyakit tuberkulosis di Rumah Sakit DKT Purwokerto. Desain penelitian yang digunakan dalam penelitian ini adalah studi deskriptif dengan pendekatan cross-sectional untuk mengetahui karakteristik pasien TB paru yang patuh berobat maupun yang tidak patuh berobat di Rumah Sakit DKT Purwokerto. Penelitian ini dilakukan di Rumah Sakit DKT Purwokerto pada bulan Mei 2018. Sampel yang diteliti pada penelitian ini adalah pasien TB paru yang patuh berobat maupun tidak patuh berobat di Rumah Sakit DKT Purwokerto periode 1 Januari - 30 Desember 2017 yang memenuhi kriteria sampel. Hasil penelitian yang telah dilakuka tidak ada hubungan antara umur dengan hasil pemeriksaan dahak di Rumah Sakit DKT Purwokerto( $p$ value $=0,286$ ), tidak ada hubungan antara jenis kelamin dengan hasil pemeriksaan dahak di Rumah Sakit DKT Purwokerto(p value= 0,261).
\end{abstract}

\section{Kata Kunci : TBC Paru, Karakteristik, Pemeriksaan Dahak}

\begin{abstract}
Pulmonary tuberculosis (TB) is a contagious pulmonary infectious disease that is still a health problem in the world, especially developing countries. Tuberculosis has been proclaimed by WHO (World Health Organization) as Global Emergency since 1992. The purpose of this study is to find out what physical characteristics are at risk of tuberculosis in DKT Hospital Purwokerto. The research design used in this study was a descriptive study with a cross-sectional approach to determine the characteristics of pulmonary $T B$ patients who were adherent to treatment and those who did not comply with treatment at the DKT Hospital in Purwokerto. This research was conducted at the DKT Purwokerto Hospital in May 2018. The samples studied in this study were pulmonary $T B$ patients who were obedient to treatment and noncompliance with treatment at the DKT Purwokerto Hospital for the period of 1 January - 30 December 2017 that met the sample criteria. The results of the study have no relationship between age and the results of sputum examination at the Purwokerto DKT Hospital ( $p$ value $=0.286$ ), there is no relationship between sex with the results of sputum examination at DKT Purwokerto Hospital ( $p$ value $=0.261$ ).
\end{abstract}

Keywords: Pulmonary TBC, Characteristics, Phlegm Examination

Vwa Medika | EDISI KHUSUS/SERI 2/ FEBRUARI/2018 


\section{PENDAHULUAN}

Tuberkulosis

(TB) paru

merupakan penyakit infeksi paru menular yang masih menjadi masalah kesehatan di dunia terutama negara berkembang. Penyakit tuberkulosis sudah dicanangkan oleh WHO (World Health Organization) sebagai Global Emergency sejak tahun 1992.

Tuberkulosis (TB) tetap menjadi salah satu ancaman terbesar di dunia yang merupakan salah satu dari 10 penyebab kematian di seluruh dunia. Pada tahun 2014 TB membunuh 1,5 juta orang dengan lebih dari $95 \%$ terjadi di negara berpenghasilan rendah dan menengah. Dari $60 \%$ total penderita TB disumbangkan oleh 6 negara yaitu India, diikuti oleh Indonesia, China, Nigeria, Pakistan dan Afrika Selatan. Kejadian multidrug (MDR-TB) pun secara global pada tahun 2015 diperkirakan mencapai 480.000 orang TB (WHO, 2015).

Secara epidemiologi, sebaran TB lebih banyak menyerang orang dewasa pada usia produktif. Akan tetapi, semua kelompok usia berisiko TB. Pada kelompok anak-anak ditemukan satu juta anak-anak (0-14 tahun) jatuh sakit karena TB, dan 170.000 anak-anak meninggal karena TB pada tahun 2015. Risiko TB aktif lebih besar pada orang yang menderita kondisi yang mengganggu sistem kekebalan tubuh. Selain itu, perilaku penggunaan tembakau sangat meningkatkan risiko penyakit $\mathrm{TBC}$ dan ke-matian. Lebih dari 20\% kasus TB di seluruh dunia disebabkan oleh merokok (WHO, 2015).

Karakteristik kelompok yang berisiko TB perlu diketahui supaya dapat meningkatkan angka penemuan kasus dan pemberian pengobatan dini. Perkiraan kasus TB menurun setelah ada program penemuan kasus pada kelompok yang berisiko tinggi tertular TB. Antara tahun 2000 sampai 2015 diperkirakan 49 juta nyawa diselamatkan melalui diagnosis dan pengobatan TB. Kejadian TB-pun dapat turun rata-rata $1,5 \%$ per tahun (Dirjen P2PL, 2017).

Di wilayah kerja Rumah Sakit DKT Purwokerto, mengenai karakteristik pasien TB belum diketahui. Oleh sebab itu, pentingnya dilakukan suatu penelitian untuk mendalami karakteristik umur dan jenis kelamin dari penderita $\mathrm{TB}$, selain untuk memudahkan keberhasilan pengobatan juga berguna untuk meningkatkan angka penemuan kasus pada kelompok berisiko TB di wilayah kerja Rumah Sakit DKT Purwokerto. 


\section{METODE PENELITIAN}

Desain penelitian yang digunakan dalam penelitian ini adalah studi deskriptif dengan pendekatan cross-sectional untuk mengetahui karakteristik pasien TB paru yang patuh berobat maupun yang tidak patuh berobat di Rumah Sakit DKT Purwokerto.

Penelitian ini dilakukan di Rumah Sakit DKT Purwokerto pada bulan Mei 2018. Sampel yang diteliti pada penelitian ini adalah pasien TB paru yang patuh berobat maupun tidak patuh berobat di Rumah Sakit DKT Purwokerto periode 1 Januari - 30 Desember 2017 yang memenuhi kriteria sampel. Sampel dipilih dengan cara pemilihan sampel tidak berdasarkan peluang (non-probabiity sampling), jenis yang digunakan adalah consecutive sampling dimana seluruh sampel penelitian dimasukkan kedalam penelitian. Variabel-variabel yang diteliti pada penelitian ini adalah umur, status perkawinan, pekerjaan, dan status gizi dengan hasil pemeriksaan dahak pasien TB paru di Rumah Sakit DKT Purwokerto periode 1 Januari - 30 Desember 2017. Pengumpulan data pada penelitian ini dilakukan dengan pendekatan crosssectional berupa data primer dari kuesioner yang dilakukan dalam satu periode yang telah ditentukan.

\section{HASIL DAN PEMBAHASAN}

\section{Analisi Univarian}

Tabel 1 Distribusi Frekuensi berdasarkan Karakteristik Penderita TB Paru di Kabupaten Ogan Ilir Tahun 2013

\begin{tabular}{cccc}
\hline $\begin{array}{c}\text { Karakteristik } \\
\text { Penderita } \\
\text { TB Paru }\end{array}$ & Kategori & Frekuensi & $\%$ \\
\hline Umur & & & \\
& 15-55 tahun & 190 & 70,4 \\
& $>55$ Tahun & 80 & 29,6 \\
\hline Jenis Kelamin & Laki-laki & 173 & 64,1 \\
& Perempuan & 97 & 35,9
\end{tabular}

\section{Hasil Pemeriksaan Dahak}

Tabel 2 Distribusi Frekuensi berdasarkan Hasil Pemeriksaan Dahak di Kabupaten Ogan Ilir Tahun 2013

\begin{tabular}{lll}
\hline $\begin{array}{c}\text { Hasil Pemeriksaan } \\
\text { Dahak }\end{array}$ & Frekuensi & Presentase \\
\hline BTA Positif & 208 & 77,0 \\
\hline BTA Negatif & 62 & 23,0 \\
\hline Total & 270 & 100 \\
\hline
\end{tabular}




\section{Analisis Bivariat}

a. Hubungan antara Umur dengan Hasil Pemeriksaan Dahak

Tabel 3 Distribusi Hubungan antara Umur dengan Hasil Pemeriksaan Dahak di Kabupaten Ogan Ilir Tahun 2013

\begin{tabular}{|c|c|c|c|c|c|c|c|}
\hline \multirow[t]{3}{*}{ Umur } & \multicolumn{4}{|c|}{ Hasil Pemeriksaan Dahak } & \multirow{2}{*}{\multicolumn{2}{|c|}{ Jumlah }} & \multirow{3}{*}{$\begin{array}{l}\text { p- } \\
\text { value }\end{array}$} \\
\hline & \multicolumn{2}{|c|}{ BTA Positif } & \multicolumn{2}{|c|}{ BTA Negatif } & & & \\
\hline & $\mathrm{N}$ & $\%$ & $\mathrm{~N}$ & $\%$ & $\mathrm{~N}$ & $\%$ & \\
\hline $\begin{array}{l}\text { Usia } \\
\text { Produktif }\end{array}$ & 143 & 53 & 47 & 17,4 & 190 & 70,4 & 0,286 \\
\hline $\begin{array}{l}\text { Usia } \\
\text { Tidak } \\
\text { Produktif }\end{array}$ & 65 & 24,1 & 15 & 5,6 & 80 & 29,6 & \\
\hline Total & 208 & 77,0 & 62 & 23,0 & 270 & 100 & 0,286 \\
\hline
\end{tabular}

b. Hubungan antara Jenis Kelamin dengan Hasil Pemeriksaan Dahak

Tabel 4 Distribusi Hubungan antara Jenis Kelamin dengan Hasil Pemeriksaan Dahak di Kabupaten Ogan Ilir Tahun 2013

\begin{tabular}{|c|c|c|c|c|c|c|c|}
\hline \multirow[t]{3}{*}{ Umur } & \multicolumn{4}{|c|}{ Hasil Pemeriksaan Dahak } & \multirow{2}{*}{\multicolumn{2}{|c|}{ Jumlah }} & \multirow{3}{*}{$\begin{array}{l}\text { p- } \\
\text { value }\end{array}$} \\
\hline & \multicolumn{2}{|c|}{ BTA Positif } & \multicolumn{2}{|c|}{ BTA Negatif } & & & \\
\hline & $\mathrm{N}$ & $\%$ & $\mathrm{~N}$ & $\%$ & $\mathrm{~N}$ & $\%$ & \\
\hline Laki-laki & 137 & 50,7 & 36 & 13,3 & 173 & 64,1 & 0,261 \\
\hline Perempuan & 71 & 26,3 & 26 & 9,6 & 97 & 35,9 & \\
\hline Total & 208 & 77,0 & 62 & 23,0 & 270 & 100 & 0,261 \\
\hline
\end{tabular}

Karakteristik Penderita TB Paru Dari tabel 1 diketahui bahwa dari 270 orang responden sebagian besar berada pada kategori umur 15-55 tahun dengan jumlah 190 orang $(70,4 \%)$ sedangkan berdasarkan jenis kelamin, persentase laki-laki lebih besar yakni sebanyak 173 orang $(64,1 \%)$. Berdasarkan status perkawinan, sebagian besar responden berstatus kawin yakni dengan jumlah 240 orang $(88,9 \%)$ dan berdasarkan pekerjaan sebagian responden yang bekerja yakni sebanyak 141 orang $(52,2 \%)$.

Hasil Pemeriksaan Dahak Dari tabel 2 diketahui bahwa sebanyak 208 orang $(77,0 \%)$ dinyatakan BTA positif sedangkan 62 orang lainnya $(23,0 \%)$ dinyatakan BTA negatif.

Hubungan antara Umur dengan Hasil Pemeriksaan Dahak

Hasil penelitian menunjukkan bahwa dari 270 responden terdapat 190 responden $(70,4)$ yang usia produktif dimana 143 
orang $(53,0 \%)$ merupakan penderita TB Paru yang BTA positf dan 47 orang $(17,4 \%)$ merupakan penderita TB Paru yang BTA negatif. Umur produktif sangat berbahaya terhadap tingkat penularan karena penderita pada umur ini penderita mudah berinteraksi dengan orang lain, mobilitas yang tinggi dan memungkinkan untuk menularkan ke orang lain serta lingkungan sekitar tempat tinggal.

\section{Hubungan antara Jenis Kelamin dengan Hasil Pemeriksaan Dahak}

Berdasarkan hasil penelitian diketahui bahwa dari 270 responden didapatkan 173 responden yang berjenis kelamin laki-laki dimana 137 orang $(50,7 \%)$ merupakan penderita TB Paru BTA Positif dan 36 orang $(26,3 \%)$ meupakan penderita TB Paru BTA negatif. Secara epidemiologi dibuktikan terdapat perbedaan antara lakilaki dan perempuan dalam hal penyakit, insidens dan kematian akibat TB Paru. Penyakit TB Paru cenderung lebih tinggi pada jenis kelamin laki-laki dibandingkan perempuan, karena jenis kelamin laki-laki sifat keterpaparan dan tingkat kerentanan lebih tinggi daripada perempuan.16 Jenis kelamin laki-laki memiliki mobilitas yang tinggi seperti petani, sopir, tukang beca dan tukang ojek dimana memerlukan tenaga yang kuat dibandingkan perempuan yang tinggal di rumah seperti pekerjaan ibu rumah tangga sehingga laki-laki kemungkinan untuk terpapar kuman TBC lebih besar.

\section{KESIMPULAN}

Hasil penelitian yang telah dilakukan tidak ada hubungan antara umur dengan hasil pemeriksaan dahak di Rumah Sakit DKT Purwokerto $(\mathrm{p}$ value $=0,286)$, tidak ada hubungan antara jenis kelamin dengan hasil pemeriksaan dahak di Rumah Sakit DKT Purwokerto (p-value=0,261).

\section{DAFTAR PUSTAKA}

Aditama, T., 2002.Tuberkulosis; Diagnosis, Terapi dan masalahnya. Ed 4. Yayasan penerbit ikatan dokter Indonesia: Jakarta.

World Health Organization (WHO), 2010, Indonesia Tuberculosis Profile, 1. http://www.who.int/ tb/country/data/ profiles/en/index.html, (1 September 2018).

Dinas Kesehatan Kalimantan Barat, 2008, Profil Kesehatan Propinsi Kalimantan Barat tahun 2007, Pontianak, free-pdfebooks.com, (2 September 2018).

Cofton, J., Miller, F., Horne, N., 2002, Clinical Tuberculosis. Macmillan Education LTD,

Sinha, T., Tiwari, S., 2010, DOTS Compliance by Tuberculosis 
Patients in District Raipur. Online J Health Allied Scs, 9(3): 12.

Chan-Yeung, M., et al, 2003, Prevalence and Predictors of Default from TuberculosisTreatment in Hong Kong. Hong Kong Med J, 9(4): 8.

Buu, T., et al, 2003, Initial Defaulting in the National Tuberculosis Program in Ho Chi Minh City, Vietnam: A Survey of Extent, Reasons, and Alternative Actions Taken Following Default, Int J Tberc Lung Dis, 7(8): 41.

Departemen Kesehatan Republik Indonesia, 2007, Pedoman Nasional Penanggulangan Tuberkulosis. DepKes RI, 1 - 127.

Zuliana, I., 2011, Pengaruh Karakteristik Individu, Faktor pelayanan kesehatan, dan Faktor Peran Pengawas Menelan Obat Terhadap Tingkat kepatuhan Penderita TB Parudalam Pengobatan di Puskesmas Pekan Labuan Kota Medan Tahun 2009 - 2010, Universitas Sumatera Utara, Medan.

Erawatyningsih, E., dkk, 2009, FaktorFaktor yang Mempengaruhi Ketidakpatuhan Berobat pada penderita Tuberkulosis Paru. Berita Kedokteran Masyarakat, 25(3): 117123.

Eliska, 2005, Karakteristik Individu, Faktor Pelayanan Kesehatan, dan Peran Pengawas Menelan Obat (PMO) Terhadap Kepatuhan Berobat Penderita TB Paru di Puskesmas Teladan Medan Tahun 2005, Universitas Sumatera Utara,
Fakultas Kesehatan Masyarakat, Medan, (Skripsi). 